\title{
The Role of the Nurse in the Neonatal Intensive Care Unit: Between the Ideal, the Real and the Possible
}

\author{
Liciane Langona Montanholi' \\ Miriam Aparecida Barbosa Merighi² \\ Maria Cristina Pinto de Jesus ${ }^{3}$
}

The nurse is one of the professionals responsible for the care directed toward the physical, mental and social development of newborns in the Neonatal Intensive Care Unit. This study aimed to comprehend the experience of nurses working in a Neonatal Intensive Care Unit. Data collection was performed in 2008, through interviews with 12 nurses working in public and private hospitals of the city of São Paulo. The units of meaning identified were grouped into three categories: Developing actions; Perceiving their actions and Expectations. The analysis was based on social phenomenology. It was concluded that the overload of activities, the reduced number of staff, the lack of materials, equipment and the need for professional improvement are the reality of the work of the nurse in this sector. To supervise the care is the possible; integral care of the newborn, involving the parents, is the ideal desired.

Descriptors: Infant, Newborn; Intensive Care Units, Neonatal; Qualitative Research.

${ }^{1}$ RN, Doctoral student in Nursing, Escola de Enfermagem, Universidade de São Paulo, SP, Brazil. Centro de Atendimento Integral à Saúde da Mulher, Universidade de Campinas, SP, Brazil. E-mail: licianelm@gmail.com.

${ }^{2}$ RN, Ph.D. in Nursing, Full Professor, Escola de Enfermagem, Universidade de São Paulo, SP, Brazil. E-mail: merighi@usp.br.

${ }^{3}$ RN, Ph.D. in Nursing, Faculdade de Enfermagem, Universidade Federal de Juiz de Fora, MG, Brazil. E-mail: cristina.pinto@acessa.com.

Corresponding Author:

Liciane Langona Montanholi

Universidade de São Paulo. Escola de Enfermagem

Av. Dr. Enéas de Carvalho Aguiar, 419

Bairro: Cerqueira César

CEP: 05403-000 São Paulo, SP, Brasil

E-mail: licianelm@gmail.com 


\section{Atuação da enfermeira na unidade de terapia intensiva neonatal: entre o ideal, o real e o possível}

O enfermeiro é um dos profissionais responsáveis pelo cuidado voltado ao desenvolvimento físico, psíquico e social do recém-nascido na unidade de terapia intensiva neonatal. Este trabalho objetivou compreender a experiência de enfermeiras que atuam em uma unidade de terapia intensiva neonatal. A coleta de dados foi realizada em 2008, por meio de entrevistas com 12 enfermeiras que atuavam em hospitais públicos e privados da cidade de São Paulo. As unidades de significado identificadas foram agrupadas em três categorias: desenvolvendo ações, percebendo suas ações e expectativas. A análise foi fundamentada na fenomenologia social. Conclui-se que a sobrecarga de atividades, o reduzido número de pessoal, a falta de materiais, equipamentos e a necessidade de aprimoramento profissional são a realidade do trabalho da enfermeira nesse setor. Supervisionar os cuidados é o possível; cuidar integralmente do recém-nascido, envolvendo seus pais, é o ideal almejado.

Descritores: Recém-nascido; Unidades de Terapia Intensiva Neonatal; Pesquisa Qualitativa.

\section{Actuación de la enfermera en la unidad de terapia intensiva neonatal: entre lo ideal, lo real y lo posible}

El enfermero es uno de los profesionales responsables por el cuidado dirigido al desarrollo físico, psíquico y social del recién nacido en la Unidad de Terapia Intensiva Neonatal. Este trabajo objetivó comprender la experiencia de enfermeras que actúan en una Unidad de Terapia Intensiva Neonatal. La recolección de datos fue realizada en 2.008, por medio de entrevistas con 12 enfermeras que actuaban en hospitales públicos y privados de la ciudad de Sao Paulo. Las unidades de significado identificadas fueron agrupadas en tres categorías: Desarrollando acciones, Percibiendo sus acciones y Expectativas. El análisis fue fundamentado en la fenomenología social. Se concluye que la sobrecarga de actividades, el reducido número de personal, la falta de materiales, equipamientos y la necesidad de perfeccionamiento profesional son la realidad del trabajo de la enfermera en ese sector. Supervisar los cuidados, es posible; cuidar integralmente del recién nacido, envolviendo sus padres, es el ideal deseado.

Descriptores: Recién nacido; Unidades de Terapia Intensiva Neonatal; Investigación Cualitativa.

\section{Introduction}

The Neonatal Intensive Care Unit (NICU) constitutes a therapeutic environment appropriate for treatment of the newborn (NB) in a serious condition. The fragility of these NBs, the increasing implementation of highrisk procedures and the low tolerance to medication errors are some of the concerns of nursing professionals working in the $\mathrm{NICU}^{(1)}$. The constant interaction with the family members of newborns requires training of the health team to offer support to them in this moment of weakness. Furthermore, the nurse is responsible for implementing a care that valorizes the physical, mental and social development of the $\mathrm{NB}^{(2)}$.

A study conducted in Argentina showed that the care for the NB by nurses in the NICU is widely recognized. Among the professionals involved in perinatal care, the nurse is one of the most essential(3). Another study conducted in the United States highlights the neonatal nurse as the mainstay of the NICU, it is she who works, together with the physician, on the treatment procedure decision, performs the direct care of the newborn and 
provides emotional support to the family members ${ }^{(4)}$. In Brazil, Article 11 of Law No. 7.498/86, which regulates the professional exercise of nursing, states that, areas exclusive to the nurse include the direct nursing care to patients with life-threatening conditions, nursing care of greater technical complexity which requires scientific knowledge and the ability to take immediate decisions $^{(5)}$; this care is evident in the NICU. The importance of the role of the nurse in the NICU can be found in the international literature ${ }^{(1-2,4,6-7)}$, however, a dichotomy is observed in the quotidian, between what is learned during training and what is performed in practice. In theory, it is perceived that the care for the NB in the NICU is an activity that is the responsibility of the nurse: in the work quotidian, these professionals present themselves as distant from the direct care for the NB and the family and focus instead on management activities. The following concerns guided this study: which activities are being performed by nurses in the NICU? Which activities are being prioritized? Are the working conditions influencing the prioritization of the direct care for the NB? What do the nurses of this unit think about their role?

This study aimed to comprehend the experience of the nurse working in a Neonatal Intensive Care Unit. The reality of their experience and meaning of their action in the context of caring for the newborn and parents was sought, aiming to produce knowledge that subsidizes the teaching and practice of care in this specialty.

\section{Methodological framework}

This is a qualitative study from the social phenomenology perspective. In reflecting on the role of nurses in the neonatal intensive care unit, the comprehension of the social group of nurses who care for newborns in the NICU was sought from the individual action. In this phenomenological approach, social action is understood as being the interpersonal relationship that is established in the life-world and that provides the intersubjective experience of the human meanings ${ }^{(8)}$. The actions of people are reasoned and these reasons are existential and not merely psychological. At the time of the action, people base themselves on past experiences, on the typifications about the world and on the practical situations that are transmitted by their family members, friends and teachers - their store of available of knowledge. The "reasons-why" are related to these experiences and typifications(9). The "reasons-for" constitute the subjective point of view of human behavior, i.e. the interpretation that people make of their actions in the social environment. Individual actions originate from conscious thoughts that are voluntary and directed toward the future. In the context of intersubjectivity, what is individual is configured in a social sense. Thus, human behavior is directed towards the realization of a project that constitutes the action, primarily interpreted by the person ${ }^{(9)}$.

In total 12 nurses were interviewed who worked in public and private hospitals which neither have the Baby-Friendly Hospital certification, nor systematically implement the Kangaroo method, although they do encourage skin to skin contact between the parents and newborn. The length of time working in the NICU of the nurses ranged from two months to 11 years, all were specialists, the majority (ten) in the area of neonatal and pediatric nursing, one in collective health and one in emergency nursing. From the issues that were highlighted during the interviews, the expectations and the way that each nurse comprehends their plans, objectives, actions, or their "reasons-for" acting in the NICU were brought into focus. The context of meaning that serves as a foundation for life projects were identified during the speech of the nurses, constituting the "reasons-why" of this social group.

The interviews were conducted at a time and place chosen by the nurses and had the guiding questions: Can you tell me about your daily routine in the NICU? How do you carry out the direct care of the NB? In addition to the activities that you have already developed, is there any other activity that you would like to perform here in the NICU? Care was taken so that the nurses felt free to describe their experiences of working in the NICU and to express their future expectations. The number of participants of this study was not predetermined. Data collection was concluded when the data began to be repeated, showing that the phenomenon had been revealed. For the data analysis, the following took place: reading and transcribing of the interviews in their entirety; grouping of aspects related to the meaning of social action; categorization and interpretation of the data according to the premise of Social Phenomenology ${ }^{(10)}$. This study met the ethical standards proposed in Resolution No. 196/96 of the National Health Council in relation to research involving human beings ${ }^{(11)}$. The project was evaluated by the Research Ethics Committee, of the School of Nursing of the University of São Paulo, under Protocol No. 713/2008. In order to maintain the anonymity of the nurses, the interviewees were identified as: E1, E2, E3... E12. 


\section{Results and Discussion}

Data were grouped into categories, considering the motivations, similarities and differences, based on the "reasons-why" and "reasons-for" of the nurses that constitute human behavior. The categories revealed were: Developing actions; Perceiving their actions and Expectations.

\section{Category 1: Developing Actions - "Reason-why"}

In this category, the nurses reported performing the management of the Unit, with regard to the provision of material resources, organization and supervision of care, and management of the nursing team through work schedules and standardization of nursing care, as shown by the following reports: [...] I resolve administrative problems, jobs vacancies, forwarding and results of examinations (E3). [...] I concentrate both on patient care and on nursing management, I work with the systematization of nursing, diagnoses, prescriptions [...] (E6).

The way these professionals perform these actions is determined by their body of knowledge and their biographically determined situation. The body of knowledge is constructed from what is inherited and learned of the social relationships and their own previous constitutions, which may be conserved and reformulated $^{(9)}$.

The management activity is one of four activities that guide the nurse and must be interlinked with educational and care activities, and research(12). The standardization of nursing care directs the thinking of the nurses toward appropriate decisions regarding nursing care to the patients, the results they want to achieve and what is the best care to meet the needs, considering the desirable outcomes ${ }^{(13)}$.

In this study, nurses perform management activities, including Nursing Care Systematization (NCS), and directly assisting the newborn when it is possible, due to the reduced number of auxiliary personnel, as exemplified by the following reports: [...] I do the work schedule of the auxiliary nurses, [...] I check the schedules of the medical prescriptions [...] I organize and check equipment, psychotropic drugs, the emergency cart [...] (E12). [...] I have to do all the administrative work, nursing care systematization, evolution, I do a bit of everything (E7). If there is not enough staff, we will perform the care, I will stay in the ward to provide assistance (E2).

The systematization of nursing guides and qualifies the nursing care, although, in practice, not all steps are systematically applied. The results of a study conducted in a medium-sized general hospital in Porto Alegre, Rio Grande do Sul, Brazil, presents an analysis of 302 medical records in which were identified, in $90 \%$ of cases, records of nursing and of physical examination. The nursing diagnosis was not found, the prescription was the least frequent and the evolution of the patients was recorded in more than $95 \%$ of these medical records ${ }^{(14)}$. Another study conducted in Mexico showed that the experience of nurses in relation to the systematization of nursing care is a routine and unnoticed action. The care was partially recorded and the professionals spent little time carefully listening and fostering a close relationship with patients(15). Thus, the systematization of nursing care needs to transcend the limits of disciplinary knowledge and to move in the direction of the dialogical perspective directed toward the other health professionals, considering the necessity of interdisciplinary work, continuity of care and connectivity of the health practices ${ }^{(16)}$.

Some nurses reported that they feel responsible for the direct care of the newborns in a critical condition and that they prioritize this, assuming the integral care, considering this the central focus of their work, as can be seen in the following statements: $I$ always try to treat the pain [... I I fit the PICC (Peripherally Inserted Central Catheter), I carry out bathing, medication, sample collection, advise the mother on breastfeeding, all invasive procedures (E4). I usually take on the most severe patients [...]. Here there are cardiac surgery patients, the complexity is very high [...] In the care of cardiopulmonary arrest, the nurse acts... (E10). [...] I give priority to care, leaving the administrative side for when I have time, because the priority is patient care (E1).

However, other nurses said they did not have time for such care, because they need to pay attention to all newborns and to the organization, performing more explicit care and in specific situations: [...] I assume only some care so that I can provide support to the other babies. I assume all the invasive care, which are functions of the nurse, such as punctures, sample collection, insertion of probes. [...] we have to prioritize what is most important, you cannot stop to look at all the children... (E9).

A study on nursing care in the NICU showed that, for the professionals, the excess of hospitalized newborns, their gravity and the reduced number of nurses hinder their work. Thus, they consider that they could provide more comprehensive and humane care if the quantity of nurses in the Neonatal Care Unit was higher ${ }^{(17)}$.

The nurses in the present study reported also meeting the care needs of the parents of the newborns, especially in relation to the bond between them. In this 
type of relationship, there is reciprocity of intentions, i.e. the nurse manages to see the world according to the perspectives of the family of the newborn, as the following reports indicate: [...] we give guidance on breastfeeding [...] we evaluate the breastfeeding (E8). [...] I love working with parents, in this context of family relationships (E12).

An international study highlighted the need for family participation in the care of newborns in the NICU, care that must be individualized and focused on their development. The Newborn Individualized Developmental Care and Assessment Program (NIDCAP) has as its main objective the promotion of work focused on the relationship with the newborns and their families, increasing family participation in the care ${ }^{(18)}$.

Some nurses reported involving the parents in the care of the newborns through touch and breastfeeding. However, they reported that they are not always available to be with the parents, there are no protocols for the care of the family and, to some team members, the presence of the parents in the NICU hinders their performance, which can be perceived in the following statements [...] I love working with parents, with the family. But there are many staff who are resistant, they prefer the baby to be restricted to the incubator and say that the mother will disturb the baby. [...] We have no standardization here (E12). I would like to do more, sometimes, when we're very busy, I become anxious; I could provide care to the parents, but I can't, because my priority at that moment is the assistance (E11).

Other nurses reported that the presence of the family in the NICU is positive and that it differentiates the care, considering the attention given to the NBs and to their parents: [...] I include the family a lot in the care [...]. This is gratifying [...] (E6). [...] it is differentiated care, in which I not only work with the newborn, but also with the mother (E1).

In a study on the interaction of the nursing professionals with the newborns and their parents during hospitalization, carried out in a hospital in São Paulo, the NB constituted the motivation for the professionals working in the NICU to communicate with the family. They seek to communicate with the baby because they like to provide them with care and because they recognize their physical and emotional dependence, in addition to the need for the formation of a bond with the NB and the family(19).

\section{Category 2: Perceiving their actions - "Reasons- why"}

The perception that nurses have of the context in which they work is related to interpersonal relationships, the way they act with the newborn and their affinity with the family members ${ }^{(7)}$.

The nurses in this study mentioned some negative factors that interfere in the care of the newborns and their families, such as the inadequate numerical ratio of staff/newborns, the deficiency of materials, the overload of administrative work, the presence of sound stimuli in the unit, the difficulty of teamwork and the lack of improvement courses to perfect direct care, as explained in the following statements: the place is very noisy, interfering a lot in the care of the newborn. [...] (E4). [...] if there were more material resources, I would develop my work better [...] (E3).

A qualitative study conducted in the Intensive Care Unit indicated as a reason for the distress and anguish of nurses the daily contact with extremes in relation to technology: the latest equipment, contrasting with other obsolete equipment, which does not serve the needs of the patients ${ }^{(20)}$.

The overload of administrative work generates dissatisfaction in the professional due to the difficulty in dedicating themselves to the direct care of the NB and to training activities, as in the following statements: $[\ldots]$ when I'm alone \{there is only one nurse on the shift\}, I have to think about everything [...] (E7). I end up losing a lot of time with the papers of the medical records, things that we, nurses, have to fill in [...] a time I might be attending a child [...] (E7). [...] I need to have more training [...] the workplace does not give freedom to improve myself (E5).

A study regarding ongoing education as a tool to think and act in nursing work corroborates the findings of this study in the sense that the care is closer to the auxiliary nurse and nursing technicians than the nurse, the latter being more concerned with administrative matters, which promotes distancing from the care. Ongoing education should constitute part of the thinking and doing of the workers, providing personal and professional growth and contributing to the organization of the work ${ }^{(21)}$.

Some nurses reported dissatisfaction with the work and association this with the fact that they feel undervalued by the work team, as well as the lack of autonomy, as shown by the following statements: [...] you devote everything that you have to your work [...] and, suddenly, you see that the others do not value your work. [...] we are an extremely divided group. [...] I've worked at other institutions, this is a general thing, a national thing [...] (E7). The physicians [...] cannot understand that sometimes you cannot do everything at that moment (E9).

The difficulties of teamwork should be discussed 
and shared so that better integration can be established which would consequently benefit the team, patient, family and institution ${ }^{(20)}$.

Mexican nurses consider themselves to be exercising autonomy when they plan and carry out interactions with the patient and family based on their needs, based on understanding and knowledge, in critical thinking and in decision making(15). The nurse experiences autonomy when evaluating the needs and conditions of the patient, communicating concerns and priorities and meeting the goals of care ${ }^{(22)}$. A study performed in São Paulo on the expectations of parents and members of the nursing team in relation to the work of the nurse in the NICU showed that the family-centered approach, interpersonal relationship techniques and differentiation between technology and scientific knowledge is a necessary requirement for the effective performance of this professional(6).

The nurses also stressed that the lack of synchrony in the teamwork prejudices the performance of all of the professionals, complicates nursing care quality and generates dissatisfaction, as indicated by the following statements: [...] we have some problems with the physicians... This ends up giving a certain dissatisfaction [...]. There are physicians who are more accessible, others are not [...] (E6).

In this sense, the theory of reciprocal intentions can be used, which is established when the person involved in a given situation reasons as if in the place of the other, experiencing the common situation from the perspective of the other person, and vice versa(9). Thus, there will only be effective teamwork in the NICU when each professional, as well as understanding the care needs of the newborns and their families, puts themselves in the place of the other professional, valorizing the performance of each team member.

After the comprehension of the motivational context, i.e. of the activities performed by the nurses and their perceptions of their role, the description of the expectations in relation to the role in the NICU was sought - the "reasons-for" expressed in their statements.

\section{Category 3: Expectations - "Reasons-for"}

Various expectations related to the care for the newborns and for the parents were given. The nurses want to minimize the suffering, the pain and the sequelae of the newborn and to promote the affective bond between them and their parents, as can be found in the following reports: [...] I want the baby to get better, to develop, to grow, [...] to be a happy person (E2). [...] I always want everything to be just right, the timing of the medication, the diet. [...] the patient needs this, stability and organization (E10). [...] I want them to go home well, but into a family context, establishing a family bond. [...] (E6).

They envisioned changes that could contribute to improving care in the NICU such as: improvement courses, training events, implementation of care protocols; humanization among the work team and a balance between administrative work and the direct care of newborns hospitalized in the NICU, as indicated in this statement: what you need is a greater operation of continuing education [...] more courses, training [...] (E3).

Another study also mentions the need for education and sensitization for the care of newborns in the neonatal ICU. It is emphasized that nurses need to have scientific knowledge and ability in order to provide quality nursing care $^{(23)}$.

While recognizing that direct care is performed, in most cases, by the auxiliary staff and the importance of the nurses in the management of the care of the newborns in the NICU, the nurse manifests the desire to be closer to the care activities, as explained in the following statement: [...] I would like it if I could assume the child integrally, but at the moment, we are unable to do this [...] because here we do not have a person to be resolving the other problems [...] (E9). I would like to do a little less administrative work, there are many roles that nurses have to fill [...] (E7).

A study performed in a philanthropic hospital in Brusque, Santa Catarina, Brazil, involving the nursing team noted as the main difficulty the fact that, when developing nursing care systematization in the intensive care unit, the nurse spends more of their quotidian time on this activity than on the usual activities. However, the possibility of achieving nursing care of the desired quality was emphasized(24). According to their store of knowledge, nurses can project their expectations regarding the care given to the newborn and the family - to develop projects for the improvement of care and for the development of their work in the NICU.

\section{Final considerations}

Through the statements of the nurses, it was possible to comprehend the reality experienced by them in the NICU, such as the overload of work, the lack of materials, the difficulty of teamwork, the lack of improvement courses and lack of professional autonomy. The action possible was to focus on the nursing care of high complexity and to delegate the other care to auxiliary nurses. In the NICU, the ideal would be, as well as to manage, to perform direct care of the newborn in order to satisfy the needs of the NBs and their family members. 
It has become urgent to sensitize the nurses and the managers of hospitals regarding the importance of the nurse performing the direct care of NBs hospitalized in a NICU. The standardization of care, coupled with ongoing education and with qualification for the management of technological resources are factors that enable the professionals to provide a good technical quality of care. However, it is necessary that the team is always attentive to the individual needs of each NB and their family. The working relationship must be constructed and, for this, the team should plan the care together, respecting the role of each professional. The adequation of nursing human resources to the needs of the NICU enables the nurse to better manage the care of the NBs and their parents. A continuing effort to resignify the practices of care by the nurses is required.

The nursing practice based on scientific evidence, the dissemination of research related to nursing care and the capacity to standardize the care, to supervise the work of the team and to prioritize and provide direct care to the NB will provide subsidies to the nurse for the realization of a humanized, high quality care. Social Phenomenology has enabled the comprehension of the role of a group of nurses in a Neonatal Intensive Care Unit, coexisting with other professionals, with newborns and their parents.

\section{References}

1. Alton M, Mericle J, Brandon D. One Intensive Care Nursery's Experience with Enhancing Patient Safety. Adv Neonatal Care. 2006;6(3):112-9.

2. Aita M, Snider L. The art of developmental care in the NICU: a concept analysis. J Adv Nurs 2003;41(3):223-32.

3. Larguía M. Prioridades para el gobierno de la ciudad de Buenos Aires en la asistencia neonatológica. Rev Hosp Mat Inf Ramón Sardá. 2000;120(3):127-32.

4. Hendricks-Munoz KD, Prendergast CC. Barries to provision of developmental care in the neonatal intensive care unit: neonatal nursing perception. Am J Perinatol. 2007;24(2):71-7.

5. Lei no 7.498, de 25 de junho de 1986 (BR). Dispõe sobre a Regulamentação do Exercício da Enfermagem e dá outras providências. Diário Oficial da União. Brasília (DF), de 26 de junho de 1986. Seção I - fls. 9.273 a 9.275 .

6. Kamada I, Rocha SMM. Parents and nursing staff's expectations regarding the nurse's work in a NICU. Rev
Esc Enferm USP. 2006; 40(3):404-11.

7. Gamboa NG. Cuidar para enfermeiros de UTI neonatal: descrição das categorias significantes [dissertação]. São Paulo (SP) Escola de Enfermagem da Universidade de São Paulo; 1997.

8. Carvalho GM, Merighi MAB, Jesus MCP. The experience of repeated fatherhood during adolescence. Midwifery. 2008. doi: 10.1016/j.midw.2008.10.007

9. Schütz A. Estudios sobre teoria social. Escritos II. Buenos Aires (AR): Amorrortu Editores; 2003.

10. Carvalho GM, Merighi MAB, Jesus MCP. Repeated adolescent parenthood from the perspective of the subjects involved. Texto Contexto Enferm. 2009; 18(1):17-24.

11. Conselho Nacional de Saúde (BR). Resolução do CSN n. 196 de 10 de outubro de 1996. Aprova as diretrizes e normas regulamentadoras de pesquisas envolvendo seres humanos. Brasília (DF); 1996.

12. Spagnol CA. (Re)pensando a gerência em enfermagem a partir de conceitos utilizados no campo da Saúde Coletiva. Ciênc Saúde Colet. 2005;10(1):119-27.

13. Cruz DALM. Processo de Enfermagem e classificações. In: Gaidzinski RR, Soares AVN, Lima AFC, Gutierrez BAO, Cruz DALM, Rogenski NMB, organizadores. Diagnóstico de Enfermagem na prática clínica. Porto Alegre: Artmed; 2008. p25-37.

14. Pokorski S, Moraes MA, Chiarelli R, Costanzi AP, Rabelo ER. Nursing process: from literature to practice. What are we actually doing? Rev. Latino-Am. Enfermagem. 2009;17(3). [acesso 24 abril 2010]. Disponível em: http://www.scielo.br/pdf/rlae/v17n3/pt_04.pdf

15. Ledesma-Delgado ME, Mendes MMR. The nursing process presented as routine care actions: building its meaning in clinical nurses' perspective. Rev. LatinoAm. Enfermagem. 2009;17(3) [acesso 24 abril 2010]. Disponível em: http://www.scielo.br/pdf/rlae/v17n3/ pt_08.pdf.

16. Backes DS, Koerich MS, Nascimento KC, Erdmann AL. Nursing care systematization as a multidimensional and interactive phenomenon. Rev. Latino-Am. Enfermagem. 2008;16(6) [acesso 24 abril 2010]. Disponível em: http://www.scielo.br/pdf/rlae/v16n6/pt_07.pdf

17. Kamada I. Assistência de Enfermagem em Unidade de Terapia Intensiva Neonatal [tese]. Ribeirão Preto (SP): Escola de Enfermagem de Ribeirão Preto da Universidade de São Paulo;2002.

18. Westrup B. Newborn Individualized Developmental Care and Assessment Program (NIDCAP) Familycentered developmentally supportive care. Early Human Develop. 2007; 83:443-9. 
19. Pinheiro EM, Silva MJP, Angelo M, Ribeiro CA. The meaning of interaction between nursing professionals and newborns/families in a hospital setting. Rev. LatinoAm. Enfermagem. 2008;16(6). [acesso 12 novembro 2009]. Disponível em: http://www.scielo.br/pdf/rlae/ v16n6/pt_12.pdf.

20. Martins JT, Robazzi MLCC. Nurses' work in intensive care units: feelings of suffering. Rev. Latino-Am. Enfermagem. 2009; 17(1) [acesso 24 de abril 2010]. Disponível em: http://www.scielo.br/pdf/rlae/v17n1/ pt_09.pdf

21. Ricaldoni CAC, Sena RR. Permanent education: a tool to think and act in nursing work. Rev. LatinoAm. Enfermagem. 2006;14(6) [acesso 24 abril 2010]. Disponível em: http://www.scielo.br/pdf/rlae/v14n6/ pt_v14n6a02.pdf

22. Gomes AMT, Oliveira DC. Espaço autônomo e papel próprio: representações de enfermeiros no contexto do binômio saúde coletiva-hospital. Rev Bras Enferm. 2008;61(2):178-85.

23. Rolim KMC, Cardoso MVLML. Interaction nursenewborn during orotracheal aspiration and blood collection. Rev Esc Enferm USP. 2006;40(4):515-23.

24. Amante LN, Rossetto AP, Schneider DG. Nursing care systematization at the intensive care unit (ICU) based on Wanda Horta's theory. Rev Esc Enferm USP. 2009;43(1):54-64. 